\title{
Bone Marrow Stem Cell
}

National Cancer Institute

\section{Source}

National Cancer Institute. Bone Marrow Stem Cell. NCI Thesaurus. Code C13456.

Primitive blood cells residing in the bone marrow, derived from embryonic mesenchyme,

and capable of differentiating into any of the blood cell line progenitor cells

(erythroblasts, young granulocytic series cells, megakaryocytes, etc.) 